\title{
NEW RECORD OF COLLEMBOLA (HEXAPODA) FROM THE PRUTUL DE JOS SCIENTIFIC RESERVE
}

\author{
Galina Bușmachiu ${ }^{1}$, Wanda Maria Weiner ${ }^{2}$ \\ ${ }^{1}$ Instite of Zoology, Chișinău, Republic of Moldova; e-mail: bushmakiu@yahoo.com \\ ${ }^{2}$ Institute of Systematics and Evolution of Animals, PAS, Kraków, Poland
}

\begin{abstract}
The paper presents new data about the species diversity of the order Collembola from the Prutul de Jos Scientific Reserve. A total of 13 species of Collembola from 11 genera and 5 families were identified for the first time in the floodplain forest of the Prutul de Jos Scientific Reserve. Among the identified collembolan species one - Endonura lusatica Dunger, 1966 is new for the fauna of the Republic of Moldova.
\end{abstract}

\section{Introduction}

Prutul de Jos Scientific Reserve was created on April 23, 1991 in order to protect the flora and fauna of Lake Beleu and the floodplains around it. The protected area is located in the lower reaches of the Prut River in the south west of the Republic of Moldova. It includes Lake Beleu and its surroundings, a network of ponds that, as a whole, form a unique ecosystem. The surface of the reserve is 1691 ha, about $1 / 3$ of its surface is occupied by the waters of lake, the rest of the territory is presented by marshy vegetation and floodplain [5]. On 2018, the reserve was registered in the UNESCO World Network of Biosphere Reserves, becoming the first biosphere reserve established in the Republic of Moldova.

\section{Material and methods}

The samples were collected in the spring 2021 in a floodplain forest located on the shores of Lake Beleu formed 27-30 years ago (fig. 1), in which white willow (Salix alba) predominates [5]. The willow forest is floodable, in which water enters during floods rising up to $1 \mathrm{~m}$. Many trees have grown too tall, others have dried up and break very easily from strong winds.

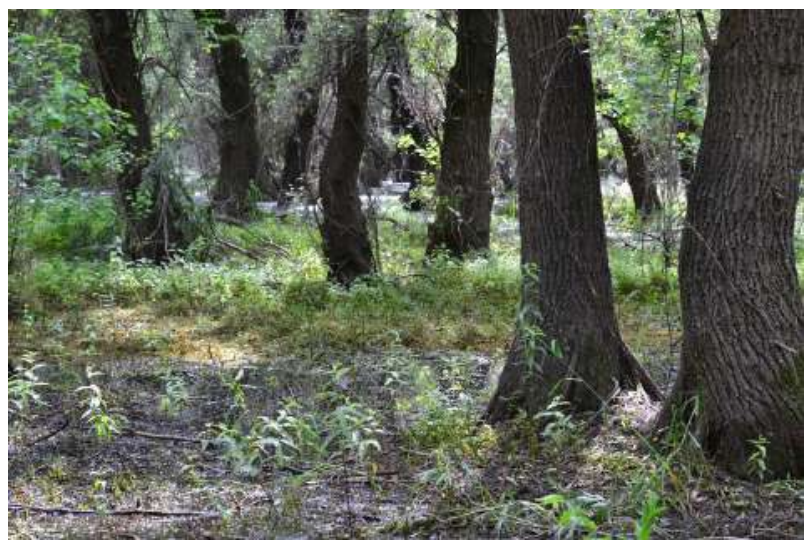

Figure 1. Floodplain forest in the Prutul de Jos Scientific Reserve 
The specimens of Collembola were extracted from decomposed wood using modified flotation method [1] then were treated with lactic acid, discolored in $\mathrm{KOH}$ and mounted in permanent slides.

The taxonomic identification of invertebrate species were performed using MBS-10, Meiji Techno binoculars, microscope Leica and determination keys [1, 6].

\section{Results and discussion}

As a result of investigation 13 species of Collembola from 11 genera and 5 families were identified for the first time in the wood decompose covered with mosses and lichens from the Prutul de Jos Scientific Reserve. Among the identified species one Endonura lusatica Dunger, 1966 from the family Neanuridae is new for the fauna of the Republic of Moldova.

Table 1. List of species identified in the Prutul de Jos Scientific Reserve

\begin{tabular}{|c|c|c|c|c|}
\hline N. & Taxon & $\begin{array}{l}\text { Data of } \\
\text { collection }\end{array}$ & $\begin{array}{l}\text { Nr. of } \\
\text { ind. }\end{array}$ & Ecology \\
\hline \multicolumn{5}{|c|}{ Neanuridae } \\
\hline 1 & *Endonura lusatica Dunger, 1966 & 23.03 .21 & 14 & $\begin{array}{c}\text { Silvicolous and } \\
\text { hydrophilous species }\end{array}$ \\
\hline \multicolumn{5}{|c|}{ Hypogastruridae } \\
\hline 2 & $\begin{array}{l}\text { Choreutinula inermis (Tullberg, } \\
\text { 1871) }\end{array}$ & 23.03 .21 & 1 & Litter species \\
\hline 3 & $\begin{array}{l}\text { Schoettella ununguiculata (Tullberg, } \\
\text { 1869) }\end{array}$ & 23.03 .21 & 44 & Euribiont \\
\hline 4 & Xenylla brevicauda Tullberg, 1869 & 23.03 .21 & 7 & $\begin{array}{l}\text { Silvicolous, briophilous } \\
\text { species }\end{array}$ \\
\hline \multicolumn{5}{|c|}{ Isotomidae } \\
\hline 5 & Isotoma riparia (Nicolet, 1842) & 23.03 .21 & 6 & Hygrophilous species \\
\hline 6 & Isotoma viridis Bourlet, 1839 & 23.03 .21 & 1 & Euribiont \\
\hline 7 & $\begin{array}{l}\text { Folsomia quadrioculata (Tullberg, } \\
\text { 1871) }\end{array}$ & 23.03 .21 & 12 & Euribiont \\
\hline 8 & Proisotoma minuta (Tullberg, 1871) & 23.03 .21 & 4 & $\begin{array}{l}\text { Ruderal and } \\
\text { thermophilous species }\end{array}$ \\
\hline \multicolumn{5}{|c|}{ Entomobryidae } \\
\hline 9 & $\begin{array}{l}\text { Entomobrya marginata (Tullberg, } \\
1871 \text { ) }\end{array}$ & 23.03 .21 & 8 & Euribiont \\
\hline 10 & Lepidocyrus paradoxus Uzel, 1890 & 23.03 .21 & 1 & $\begin{array}{l}\text { Mesophilous species with } \\
\text { preference for wet habitat }\end{array}$ \\
\hline 11 & $\begin{array}{l}\text { Lepidocyrtus violaceus Lubbock, } \\
1873\end{array}$ & 23.03 .21 & 13 & $\begin{array}{l}\text { Silvicolous species with } \\
\text { preference for wet habitat }\end{array}$ \\
\hline 12 & $\begin{array}{l}\text { Willowsia nigromaculata (Lubbock, } \\
1873 \text { ) }\end{array}$ & 23.03 .21 & 1 & $\begin{array}{l}\text { Corticicolous and } \\
\text { silvicolous species }\end{array}$ \\
\hline \multicolumn{5}{|c|}{ Katiannidae } \\
\hline 13 & Sminthurus sp. & 23.03 .21 & 1 & \\
\hline
\end{tabular}


The analysis of the wood decompose covered by moss collected along the banks of Prut River using collembolan communities' structure emphasized several peculiarities of collembolan species diversity and distribution in riparian habitat. Thus, if we compare the list of species identified in the Prutul de Jos Scientific Reserve with other habitats located along the Prut River no euedaphic species were found [3].

The revealed species presented different types of the hygropreference, the largest part of them are mesophilous and silvicolous species (Tab. 1).

New revealed species Endonura lusatica Dunger, 1966 is the second species from genus Endonura identified in the Republic of Moldova. According to research conducted by Smolis it is one of the most hygrophilous species of the genus [6].

The riparian habitats remain rather attractive places for the soil invertebrates due to the carry-over and accumulation on their surface of the biogenic elements. Thereby, Collembola inhabited all the studied localities from the banks of Prut and Dniester Rivers and their species diversity is varying $[1,2,3,4]$

Acknowledgements. The study was performed under the project N. 20.80009.7007.02. The author would like to thanks Viorica Paladi for the help in collecting of material.

\section{Bibliography}

1. Buşmachiu G. Fauna collembolelor (Hexapoda: Collembola) din Republica Moldova. Chișinău, 2021. Căpăţină Prinț, 200 p.

2. Buşmachiu G. Collembola (Hexapoda) from the riparian habitats of the Dniester River. Muzeul Olteniei, Craiova. Studii şi comunicări. Ştiinţele Naturii. Craiova, 2011, V. 27 (1), p. 63-70.

3. Buşmachiu G., Kováč L., Miklisová D., Weiner W. 2017. Riparian Collembola (Hexapoda) communities of Northern Moldova, Eastern Europe. Zookeys. 724:119-134.4.

4. Buşmachiu G., Weiner W. Collembola from the Moldavian banks of Dniester river. New records. Annales Zoologici. Warsaw, 2013. 63(4): 529-535.5.

5. Postolache G., Munteanu A., Postolache D., Cojan C. Rezervația Prutul de Jos. Chișinău, 2012. Tipografia Centrală, 152 p.

6. Smolis A. Redescription of four Polish Endonura Cassagnau, 1979 (Collembola, Neanuridae, Neanurinae), with a nomenclature of the ventral chaetae of antennae. Zootaxa, 2008, 1858 (1): 9-36. 